\title{
NON-TERPENOID C-15 METABOLITES FROM THE RED SEAWEED LAURENCIA PINNATIFIDA ${ }^{1}$
}

\author{
A. G. González,* J. D. Martín, V. S. Martín, M. Norte, R. Pérez and J. Z. Ruano \\ Department of Organic Chemistry, University of La Laguna, Institute of Organic Natural Products, La Laguna, \\ Tenerife, Canary Islands, Spain
}

and

\author{
S. A. DREXLER and J. ClaRdY*
}

Department of Chemistry, Cornell University, Ithaca, NY 14853, U.S.A.

(Received in UK 6 August 1981)

\begin{abstract}
The structures and absolute configurations of three halogenated vinyl acetylenes which are natural products from the red alga Laurencia pinnatifida (Gmal. Lamour) are described. The structure of transpinnatifidenyne 2 was determined by spectral, chemical and X-ray diffraction analyses. The structure of cispinnatifidenyne 1 is based on spectral comparison and chemical interconversion with the trans-isomer 2 . The structure of the acyclic trienyne 8 was secured as: $(6 R, 7 R)$-3-cis,9-cis,12-cis,6-acetoxy,7-chloropentadeca-3,9,12trien-1-yne by synthesis from cis-pinnatifidenyne 1 . The reactivity of these compounds to various conditions of catalytic hydrogenation has been examined in detail.
\end{abstract}

Our chemical studies on the marine alga Laurencia (Rhodomelaceae, Rhodophyta) have been concerned with assessing the diversity of halogen-based secondary metabolite biosynthesis in this genus. As part of this program we have described the structures of several halogenated sesquiterpenoids $s^{2}$ which have been important in understanding terpenoid biogenesis in this alga.

Of the large number of metabolites isolated from algae of the Laurencia genus, most are halogenated sesquiterpenes ${ }^{3}$ but a smaller group consists of halogenated cyclic ethers characterized by a straight-chain $\mathrm{C}_{15}$ carbon skeleton and a terminal enyne function. ${ }^{4}$ The latter appear to be restricted to Laurencia, related compounds found in Aplysia ${ }^{5}$ (opisthobrach molluscs) probably having a dietary origin in Laurencia.

In the present work we describe, among others, the isolation from $L$. pinnatifida (Gmal.) Lamour of two new $\mathrm{C}_{15}$ halogenated acetylenic cyclic ethers, designated as cis-pinnatifidenyne and trans-pinnatifidenyne for which we propose formulae 1 and 2.

Cis-Pinnatifidenyne 1 , m.p. $47.5-48.5^{\circ},\{\alpha\}_{\mathrm{D}}^{25}+39$ (c, $\left.13.8 \mathrm{CHCl}_{3}\right)$ was obtained in high yield $(0.05 \%$ dry weight) by column chromatography of an ether extract of the alga. Purified, neat samples of $\mathbf{1}$ deteriorated slowly at room temperature and hence no combustion analysis was obtained. The high resolution mass spectrum of cis-pinnatifidenyne indicated an elemental composition of $\mathrm{C}_{15} \mathrm{H}_{20} \mathrm{BrClO}$. The presence of a conjugated terminal enyne group similar to that present in laureatin, a related compound, ${ }^{4}$ was indicated by $\mathrm{IR}(\mathrm{KBr})$ absorption 3300 and $2100 \mathrm{~cm}^{-1}$ and UV absorption at $\lambda_{\max }(\mathrm{EtOH})$ $222.6 \mathrm{~nm}(\epsilon=13.200)$. The ${ }^{1} \mathrm{H}-\mathrm{NMR}$ spectrum of 1 (Table 2) presented signals which could be assigned to a cisenyne function, two non-conjugated olefinic protons, two $\alpha$-ether protons and two $\alpha$-halogen protons. The ${ }^{13} \mathrm{C}$ NMR spectrum of 1 (Table 1) revealed that, in addition to the acetylene carbons, two disubstituted double bonds were also present in the molecule.

Trans-Pinnatifidenyne 2, m.p. $57-58^{\circ},\{\alpha\}_{\mathrm{D}}^{25}+62$ (c, 8.9, $\mathrm{CHCl}_{3}$ ), was isolated by chromatography as a more polar constituent $(0.025 \%$ dry weight). Mass spectral analysis established that this new halogenated ether has the same elemental composition $\mathrm{C}_{15} \mathrm{H}_{20} \mathrm{BrClO}$ as cis-pinnatifidenyne 1; indeed, the fragmentation patterns of 1 and 2 were virtually identical. The presence in 2 of a terminal acetylene group conjugated with a double bond was indicated by IR $\left(3300,2115 \mathrm{~cm}^{-1}\right)$ and UV data $\left(\lambda_{\max }\right.$ $224 \mathrm{~nm}$, shoulder $232 \mathrm{~nm} ; \epsilon 16.400,11.000$ ). The larger extinction coefficient in the UV spectrum of 2 relative to that of 1 suggested the trans geometry for the double bond of the enyne group. Comparison of the ${ }^{13} \mathrm{C}$ - and ${ }^{1} \mathrm{H}-\mathrm{NMR}$ spectra of 1 and 2 revealed great similarity in structure between the two compounds and at the same

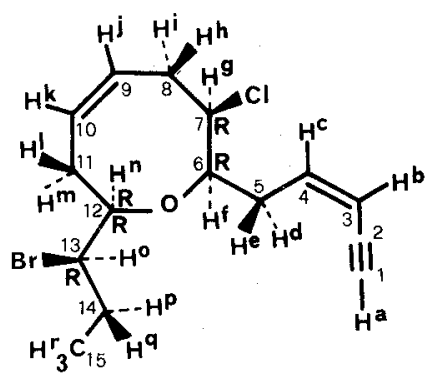

$\stackrel{1}{\sim}$

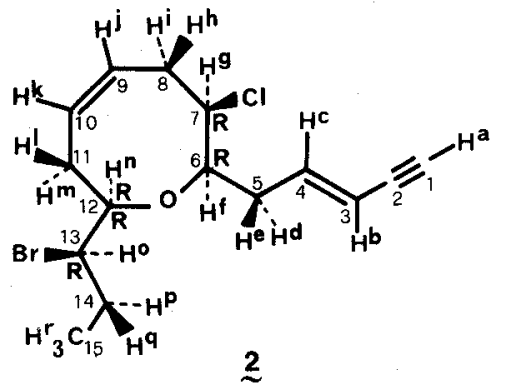


Table $1 .{ }^{13} \mathrm{C}-\mathrm{NMR}$ assignments for cis- and trans-pinnatifidenyne and related ${ }^{a, 0}$

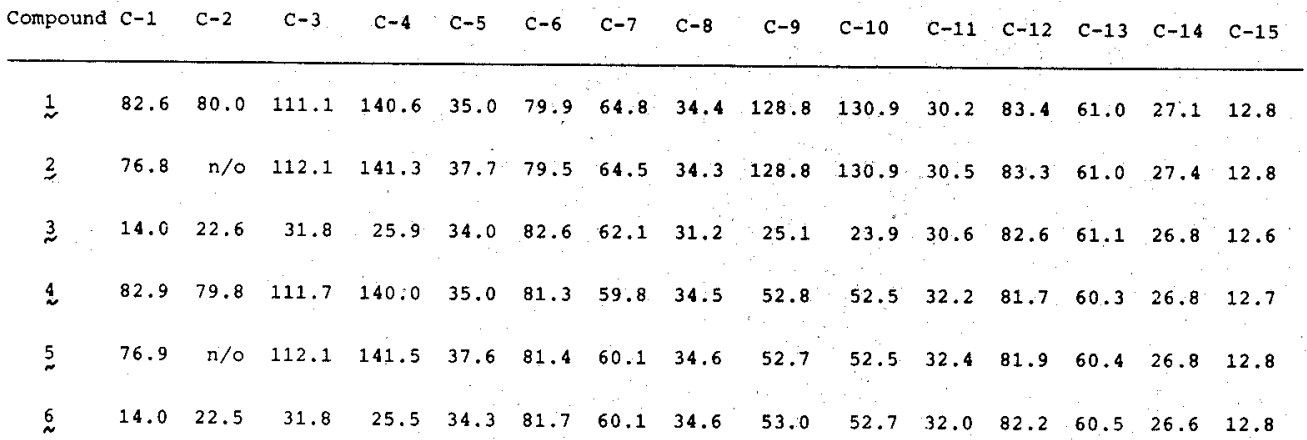

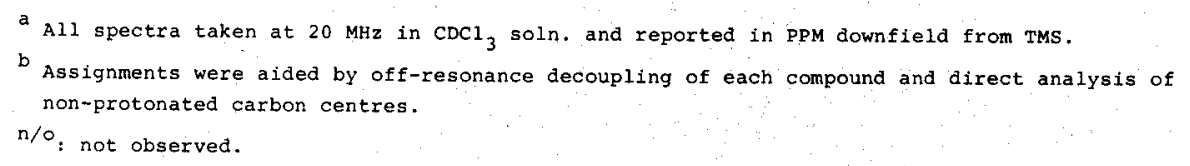

time confirmed that the enyne double bond of $\mathbf{1}$ is cis and of $\mathbf{2}$ is trans (see Tables).

Catalytic hydrogenation of 1 afforded an oily octahydro derivative $3\left(\mathrm{C}_{15} \mathrm{H}_{28} \mathrm{BrClO}\right)$, which is identical, included the optical rotation, with that obtained from 2 . This confirmed that both compounds are identical with respect to carbon skeleton, size and location of the ether ring, type halogen substitution and stereochemistry of all substituents. The complete structure and absolute configuration of trans-pinnatifidenyne were determined by single crystal X-ray diffraction. A suitable single crystal was obtained by recrystallization from a hexane-ether mixture. Compound 2 crystallized in the triclinic space group P1 with $a=5.454(4), b=8.882(7), c=10.072(7) \AA, \alpha$ $=105.97(6), \beta=68.86(6)$ and $\gamma=75.64(7)^{\circ}$ and one molecule of $\mathrm{C}_{15} \mathrm{II}_{20} \mathrm{BrClO}$ per unit cell. The structure was solved routinely by the heavy atom method using the $1010(85 \%)$ unique observed $\left(\mathrm{F}_{0}^{2} \geqslant 3 \sigma\left(\mathrm{F}_{0}^{2}\right)\right)$ reflections. The current residual is 0.084 for the structure and significantly higher for the enantioner. ${ }^{6}$ Figure 1 is a stereoscopic drawing of the molecule in which the absolute configuration is represented.

The identical location of the endocyclic double-bond in both isomers was established by selective epoxidation of 1 (or 2) to give the epoxiderivative 4 (or 5) which was hydrogenated to give the hexahydroderivative 6.

Detailed spectral comparison of cis- and trans-pinnatifidenyne and derivatives with the previously described vinyl acetylenes: rhodophytin, chondriol and related natural compounds ${ }^{7}$ serve as a basis for the

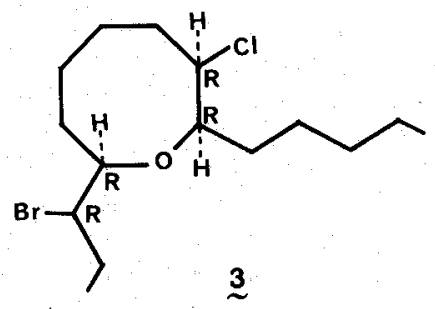

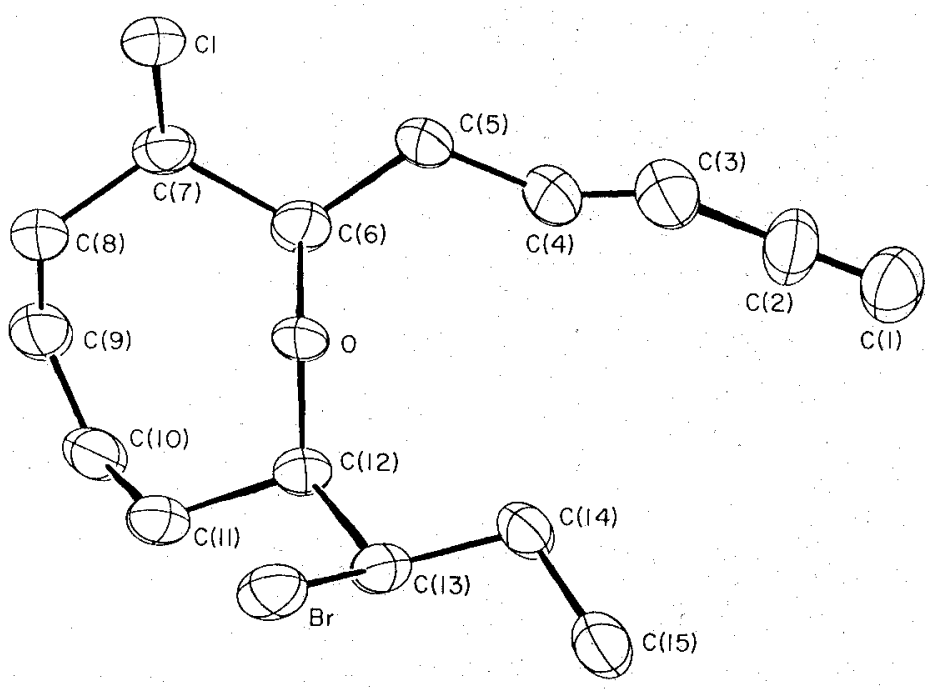

Fig. 1. A computer generated perspective drawing of the X-ray model of trans-pinnatifidenyne (2). 
Table 2.

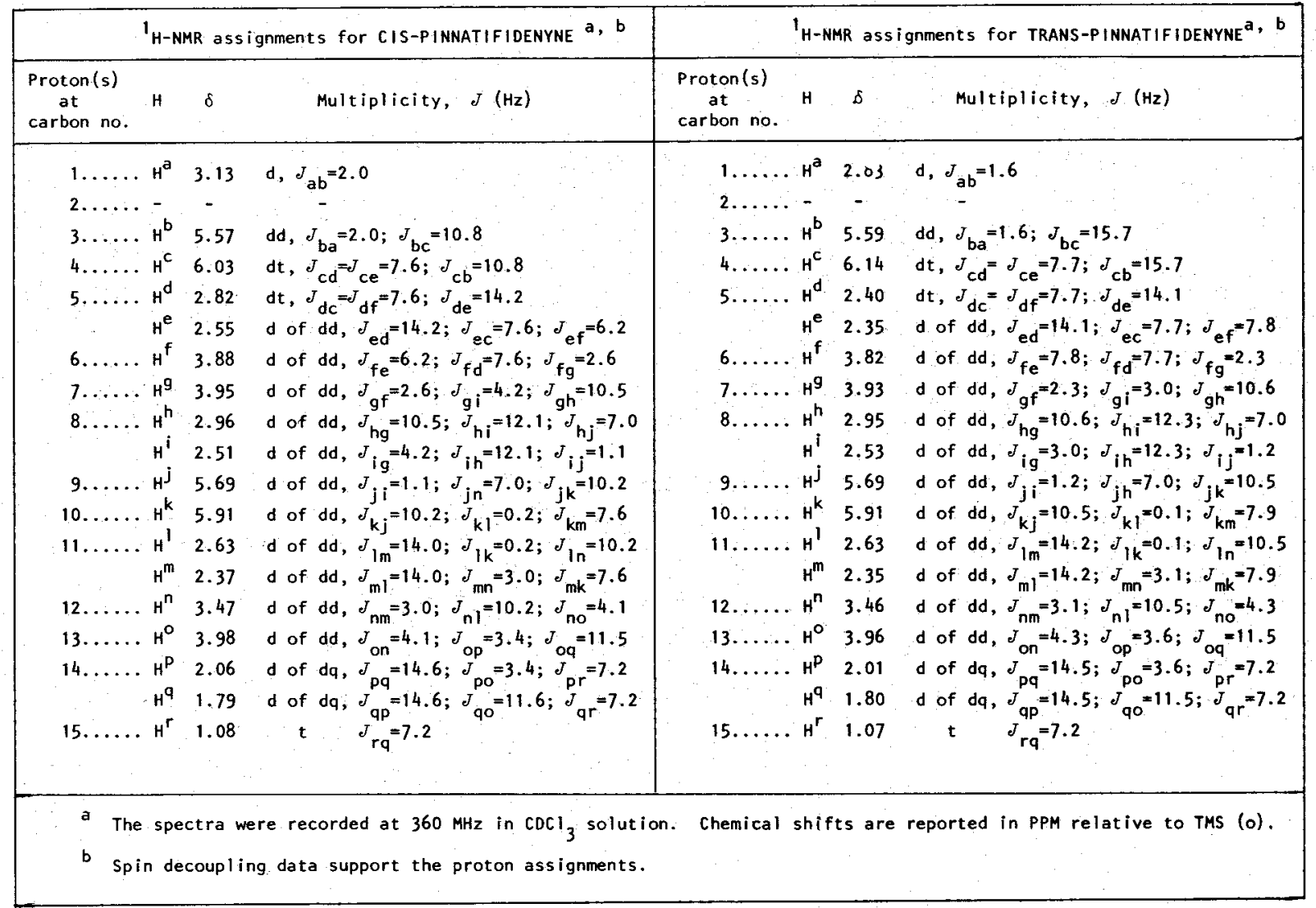




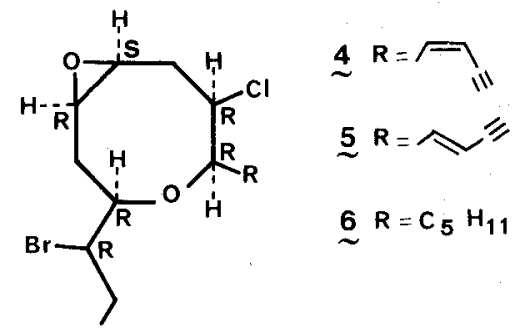

structural proposal of 1 and 2 and the spectroscopic ${ }^{13} \mathrm{C}$ and ${ }^{1} \mathrm{H}-\mathrm{NMR}$ assignments (Tables 1 and 2).

In addition several more polar halogenated compounds were identified in subsequent fractions of the lipid extract. From the hexane-ethyl acetate (5:1) eluent was isolated the chlorinated alcohol $\mathbf{8}$, as a light mobile oil, $\{\alpha\}_{\mathrm{D}}^{25}+4.5\left(\mathrm{c}, 11.0 ; \mathrm{CHCl}_{3}\right)$ in $0.0012 \%$ yield. Mass spectral analysis established the molecular formula $\mathrm{C}_{17} \mathrm{H}_{23} \mathrm{ClO}_{2}$. The IR absorption of 8 showed the terminal acetylene $\left(3300 \mathrm{~cm}^{-1}\right)$, ester group $\left(1720 \mathrm{~cm}^{-1}\right)$, and multiple double bonds $\left(3030\right.$ and $1640 \mathrm{~cm}^{-1}$ ). The UV absorption $\lambda_{\max }$ $(\mathrm{EtOH}) 224 \mathrm{~nm}(\epsilon 13.100)$ indicate the presence of a conjugated cis-enyne group similar to that present in cis-pinnatifidenyne 1. The ${ }^{1} \mathrm{H}-\mathrm{NMR}$ and ${ }^{13} \mathrm{C}$-NMR spectral of 8 presented signals which could be assigned to one terminal acetylene group and three disubstituted double bonds. Treatment of compound 8 with $\mathrm{K}_{2} \mathrm{CO}_{3}$ in $\mathrm{MeOH}$ at $0^{\circ}$ gave a mixture of the alcohol 9 and the epoxide 12. Further treatment of 9 with $\mathrm{K}_{2} \mathrm{CO}_{3}-\mathrm{MeOH}$ at room temp gave 12 as the only product. The $8 \rightarrow 9 \rightarrow 10$ transformation shows a vic $\mathrm{O}$ and $\mathrm{Cl}$ orientation.

In order to correlate chemically compound $\mathbf{8}$ with cis-pinnatifidenyne 1 , this compound was treated with $\mathrm{Zn}-\mathrm{AcOH}-\mathrm{EtOH}$ under different reaction conditions. Contrarily to reports of similar cases, ${ }^{8}$ apart from the expected heterocyclic ring opening, partial hydrogenation of the acetylenic system also took place, the only isolable product obtained being the tetraolefinic derivative cis, cis, cis - $6 R$ - hydroxy $-7 R$ - chloro pentadeca $1,3,9,12$ - tetraene 13 . So as to protect the terminal acetylene, the trimethylsilyl derivative of $\mathbf{1}$,

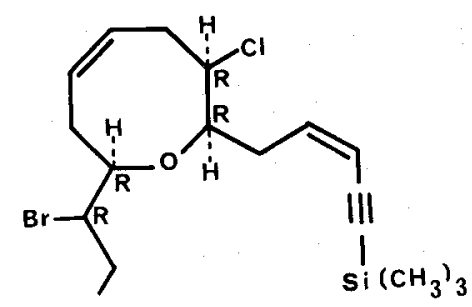

$\stackrel{7}{\sim}$

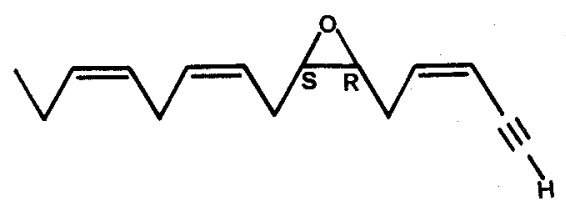

compound 7 , was prepared, by treatment of 1 with $\mathrm{n}-\mathrm{BuMgBr}-\mathrm{ClSi}\left(\mathrm{CH}_{3}\right)_{3}$ in dry THF. Compound 7 was treated with $\mathrm{Zn}-\mathrm{AcOH}-\mathrm{EtOH}$ at room temp to give the 1 - trimethylsilyl derivative of cis,cis,cis - $6 R$ - hydroxy $7 R$ - chloro - pentadeca - 3,9,12 - trien - 1 - yne 10 , which was acetylated with $\mathrm{Ac}_{2} \mathrm{O}$-py at room temp to give the acetate 11. By treatment with sodium fluoride (in DMF, $40^{\circ}, 4 \mathrm{hr},{ }^{9,10}$ compound 11 was readily converted into compound 8 in $94 \%$ yield, which was shown to be identical in all respects, included optical rotation, with the natural product. Hence compound 8 is $(6 R, 7 R)-3$ cis, 9 - cis, 12 - cis - 6 - acetoxy - 7 - chloro - pentadeca $3,9,12$ - trien - 1 - yne.

\section{EXPERIMENTAL}

M.ps were determined on a Kofler block and are uncorrected. Infrared spectra were recorded on a Perkin-Elmer Model 237 spectrophotometer and ultraviolet spectra recorded on a PerkinElmer Model 137 or a Unicam SP 800. Optical rotations were determined for solutions in chloroform with a Perkin-Elmer 141 polarimeter. 'H-NMR spectra were recorded on Perkin-Elmer R-12B (60 MHz) or R-32 (90 MHz) spectrometers, chemical shifts are reported relative to $\mathrm{Me}_{4} \mathrm{Si}(\delta 0)$ and coupling constants are given in hertz; Q1/2 refers to the width of a band at half height. ${ }^{13} \mathrm{C}$-NMR spectra were recorded on a Varian CFT-20 spectrometer. Low-resolution mass spectra were obtained from a Hewlett-Packard 5930-A mass spectrometer and high-resolution from a VG-Micromass ZAB-2F. Column and dry column chromatography were performed on silica gel $0.2-0.5$ and $0.005-$ $0.2 \mathrm{~mm}$, respectively, and TLC and PLC on silica gel 6, all Merck products. Tlc pallates were developed by spraying with $6 \mathrm{~N}$ sulphuric acid and heating. All solvents were purified by standard techniques. Anhydrous sodium sulphate was used for drying solutions.

Collection and isolation. Laurencia pinnatifida was collected in April-May 1977, by hand, using SCUBA $(-2$ to $-10 \mathrm{~m})$ near Los Cristianos, Tenerife. Air dried seaweed $(8.5 \mathrm{~kg})$ was extracted with $\mathrm{MeOH}$ and the $\mathrm{MeOH}$ soln was concd in vacuo. The residue was percolated with ether and the ethereal soln washed with water. After evaporation of the solvent, a pale yellow oil $(90 \mathrm{~g})$ was obtained and chromatographed on Florisil $(1500 \mathrm{~g})$. One-litre fractions were collected employing the following elution scheme: hexane, fraction 1-10; benzene/hexane (1/1), fractions 11-14; benzene, fractions 15-24; ethyl acetate, fractions 25-32. Fractions exhibiting similar tlc profiles were combined. A portion $(3.4 \mathrm{~g})$ of combined fractions $8-19(32 \mathrm{~g})$ was chromato-

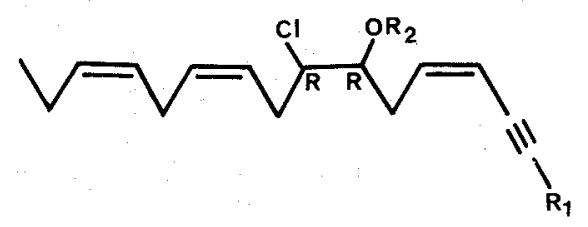

$$
\begin{aligned}
& 8 \mathrm{R}_{1}=\mathrm{H} \quad \mathrm{R}_{2}=\mathrm{AC} \\
& \stackrel{9}{9} R_{1}=H \quad R_{2}=H \\
& 10 \quad R_{1}=\operatorname{Si}\left(\mathrm{CH}_{3}\right)_{3} \quad R_{2}=\mathrm{H} \\
& 11 R_{1}=\operatorname{Si}\left(C_{3}\right)_{3} \quad R_{2}=A C
\end{aligned}
$$

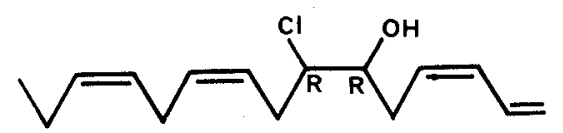


graphed on $60 \mathrm{~g}$ of silica gel $\mathrm{H}$ using $n$-hexane-ethyl acetate $(95: 5)$ as solvent and collecting $20-\mathrm{ml}$ fractions. cisPinnatifidenyne $(425 \mathrm{mg})$ crystallized from the material obtained in fractions $12-22(620 \mathrm{mg})$. Fractions $27-32$ yielded trans-pinnatifidenyne $(118 \mathrm{mg})$. After 40 fractions had been collected, two 250-ml fractions were collected using n-hexane-ethyl acetate (5:1) and this yielded $11 \mathrm{mg}$ of compound 8. All attempts to crystallize compound 8 were unsuccessful.

cis-Pinnatifidenyne 1 was recrystallized from $n$-hexane: m.p. 47.5-48.5,$\{\alpha\}_{\mathrm{D}}^{25}+39\left(\mathrm{c}, 13.8 ; \mathrm{CHCl}_{3}\right) ; \mathrm{IR}(\mathrm{KBr}) 3300,3040,2100$; $1450,1380,1320,1300,1100,970,800$ and $740 \mathrm{~cm}^{-1}$. Anal. Calc. for $\mathrm{C}_{15} \mathrm{H}_{20} \mathrm{BrClO}$ : mol wt calculated for $\mathrm{C}_{15} \mathrm{H}_{20}{ }^{79} \mathrm{Br}^{35} \mathrm{ClO}$, 330.0921. Found (high resolution mass spectrum appeared at $m / e$ $295,297\left(\mathrm{M}^{+}-\mathrm{Cl}\right) ; 265,267,269\left(\mathrm{M}^{+}-\mathrm{C}_{5} \mathrm{H}_{5}\right) ; 251,253\left(\mathrm{M}^{+}-\mathrm{Br}\right)$ and $209,211\left(\mathrm{M}^{+}-\mathrm{C}_{3} \mathrm{H}_{6} \mathrm{Br}\right)$.

Trans-Pinnatifidenyne 2 was crystallized from $n$-hexane: m.p. $57-58^{\circ} \mathrm{C},\{\alpha\}_{\mathrm{D}}^{25}+62\left(\mathrm{c}, 8.9, \mathrm{CHCl}_{3}\right)$; IR (KBr) 3300, 3050, $2100,1460,1420,1200,1100$ and $1050 \mathrm{~cm}^{-1}$. Recrystallization from an ether/hexane mixture yielded large, colourless crystals which were utilized for X-ray crystallographic analysis. The molecular ion was extremely weak but could be detected by chemical ionization. Mass spectrometry with ammonia as the carrier gas led to an unambiguous molecular weight of 330, 332, 334, while mass spectrometry under all other conditions had furnished only $\mathrm{M}^{+}-\mathrm{Br}$. Anal. Calc. for $\mathrm{C}_{15} \mathrm{H}_{20} \mathrm{BrClO}$ : mol wt calculated for $\mathrm{C}_{15} \mathrm{H}_{20}{ }^{35} \mathrm{Cl}^{79} \mathrm{BrO}, 330.0921$. Found: molwt 330.0921. Significant peaks in the mass spectrum appeared at m/e 265, 267, $269\left(\mathrm{M}^{+}-\mathrm{C}_{5} \mathrm{H}_{5}\right) ; 251,253\left(\mathrm{M}^{+}-\mathrm{Br}\right)$, and 209, $211\left(\mathrm{M}^{+}-\right.$ $\mathrm{C}_{3} \mathrm{H}_{6} \mathrm{Br}$ ).

$(6 R, 7 R)$ - 3 - cis,9 - cis, 12 - cis, 6 - acetoxy,7 - chloro pentadeca - 3,9,12 - trien - 1 - yne 8 was isolated as an oil, $\{\alpha\}_{\mathrm{D}}^{25}+4.54$ (c, $11.0 ; \mathrm{CHCl}_{3}$ ); IR (film) 3300, 2990, 2955, 2920, $2870,1730,1430,1370,1220,1030$ and $960 \mathrm{~cm}^{-1}$; UV (EtOH) $224 \mathrm{~nm}(\epsilon=13100)$. ${ }^{1} \mathrm{H}-\mathrm{NMR}\left(90 \mathrm{MHz}, \mathrm{CCl}_{4}, \delta\right.$-scale) $0.97(3 \mathrm{H}, \mathrm{t}$, $\mathrm{J}=8 \mathrm{~Hz}), 2.01(2 \mathrm{H}, \mathrm{m}), 2.06(3 \mathrm{H}, \mathrm{s}), 2.50(2 \mathrm{H}, \mathrm{m}), 2.73(4 \mathrm{H}, \mathrm{M})$, $3.08(1 \mathrm{H}, \mathrm{d}, \mathrm{J}=2 \mathrm{~Hz}), 3.90(1 \mathrm{H}, \mathrm{m}), 5.08(1 \mathrm{H}, \mathrm{m}), 5.37(4 \mathrm{H}, \mathrm{m})$, $5.55(1 \mathrm{H}, \mathrm{dd}, \mathrm{J}=2$ and $8 \mathrm{~Hz})$, and $5.95(1 \mathrm{H}, \mathrm{dt}, \mathrm{J}=7$ and $8 \mathrm{~Hz})$. ${ }^{13}$ C-NMR (20 MHz, $\left.\mathrm{CDCl}_{3}\right) 14.2(\mathrm{q}), 20.6(\mathrm{q}), 20.9(\mathrm{t}), 25.8(\mathrm{t})$, $32.3(\mathrm{t}), 32.5(\mathrm{t}), 75.45$ (d), 78.64 (d), 81.77 (s), 83.74 (d), 111.8 (d), 124.6 (d), 126.5 (d), 131.7 (d), 132.4 (d), 138.9 (d). Mass spectrum: $\mathrm{M}^{+}$m/e 296, $294\left(\mathrm{C}_{17} \mathrm{H}_{23} \mathrm{ClO}_{2}\right)$. Further peaks at $m / e: 201,199$ $\left(\mathrm{C}_{10} \mathrm{H}_{12} \mathrm{ClO}_{2}\right) ; 199\left(\mathrm{C}_{15} \mathrm{H}_{19}\right), 193\left(\mathrm{C}_{12} \mathrm{H}_{17} \mathrm{O}_{2}\right) ; 171,169\left(\mathrm{C}_{10} \mathrm{H}_{14} \mathrm{Cl}\right)$, $151\left(\left(\mathrm{C}_{10} \mathrm{H}_{15} \mathrm{O}\right), 129\left(\mathrm{C}_{10} \mathrm{H}_{9}\right)\right.$ and $108\left(\mathrm{C}_{8} \mathrm{H}_{12}\right)$.

Catalytic hydrogenation method. Between $10-100 \mathrm{mg}$ of each compound to be hydrogenated was dissolved in $30 \mathrm{ml}$ of anhyd diethyl ether and added to a $50 \mathrm{ml}$ Erlenmeyer suction flask containing a catalytic amount of $10 \% \mathrm{Pd}-\mathrm{C}(10 \mathrm{mg})$ and a magnetic stirring bar. The reaction vessel was fitted with a balloon and septum, purged with hydrogen and the balloon filled. After stirring at $25^{\circ}$, the hydrogen was removed, the soln filtered and the ether evaporated to give, after thick-layer silica gel chromatography (plc), purified reaction products.

Octahydropinnatifidenyne 3. (A) From cis-pinnatifidenyne 1. Catalytic hydrogenation of $\mathbf{1}$ for $1.5 \mathrm{~h}$ gave the octahydro derivative 3 in $97 \%$ yield after plc (10\% diethyl ether- $\mathbf{n}$-hexane) purification: oil, $\{\boldsymbol{\alpha}\}_{\mathrm{D}}+4.2\left(\mathrm{c}, 5.5, \mathrm{CHCl}_{3}\right)$; IR $\left(\mathrm{CHCl}_{3}\right) 3000,2960$, $2860,1450,1415,1345,1310$ and $1070 \mathrm{~cm}^{-1}$. ${ }^{1} \mathrm{H}-\mathrm{NMR}(60 \mathrm{MHz}$, $\left.\mathrm{CDCl}_{3}\right) 80.95$ (bs, $\left.3 \mathrm{H}\right), 1.05(3 \mathrm{H}, \mathrm{t}, \mathrm{J}=7 \mathrm{~Hz}), 3.70(2 \mathrm{H}, \mathrm{m}), 3.95$ $(1 \mathrm{H}, \mathrm{m}), 4.29(1 \mathrm{H}, \mathrm{dt}, \mathrm{J}=9 \mathrm{~Hz})$. Mass spectrum $\mathrm{M}^{+}$at $m / e$. 342 , 340, $338\left(\mathrm{C}_{15} \mathrm{H}_{28} \mathrm{BrClO}\right) ; 262,260\left(\mathrm{M}^{+}-\mathrm{Br}\right) ; 261,259\left(\mathrm{M}^{+}-\mathrm{HBr}\right)$; 219, $217\left(\mathrm{M}^{+}-\mathrm{C}_{3} \mathrm{H}_{6} \mathrm{Br}\right)$. Anal. Calc. for $\mathrm{C}_{15} \mathrm{H}_{28} \mathrm{BrClO}: \mathrm{C}, 52.87 ; \mathrm{H}$, $8.58 ; \mathrm{Br}, 23.45 ; \mathrm{Cl}, 10.40$. Found: $\mathrm{C}, 53.12 ; \mathrm{H}, 8.42 ; \mathrm{Br}, 23.31 ; \mathrm{Cl}$, 10.51 .

(B) From trans-pinnatifidenyne 2. Hydrogenation of 2 for $2 \mathrm{hr}$ in the same manner as described above for 1 gave in $92 \%$ yield after plc purification the octahydro derivative 3 : oil, $\{\alpha\}_{\mathrm{D}}+4.5$ (c, 2.32, $\mathrm{CHCl}_{3}$ ). IR, NMR and MS same as described in (A) above.

Cis-Pinnatifidenyne-8,9-epoxide 4. $m$-Chloroperbenzoic acid $(190 \mathrm{mg})$ in dry benzene $(10 \mathrm{ml})$ was added dropwise to a soln of cis-pinnatifidenyne $1(300 \mathrm{mg})$ in benzene $(10 \mathrm{ml})$ with stirring. After $2 \mathrm{hr}$, calcium hydroxide was added to remove the excess of peracid; the soln was then filtered and evaporated. The residue obtained was applied to one large preparative plate and this was eluted four times with light petroleum-ether (20:1). The major band afforded cis-pinnatifidenyne-8,9-epoxide $4(190 \mathrm{mg}$, 63\%): oil, $\{\alpha\}_{\mathrm{D}}^{25}+45.2\left(\mathrm{c}, 12.3, \mathrm{CHCl}_{3}\right.$ ); IR (film) $3280,2950,2120$, $1650,1450,1380,1200$ and $1100 \mathrm{~cm}^{-1} .{ }^{1} \mathrm{H}-\mathrm{NMR}\left(60 \mathrm{MHz}, \mathrm{CDCl}_{3}\right)$ $\delta 1.03(3 \mathrm{H}, \mathrm{t}, \mathrm{J}=7.2 \mathrm{~Hz}), 3.2(1 \mathrm{H}, \mathrm{d}, \mathrm{J}=2 \mathrm{~Hz}), 3.8(4 \mathrm{H}, \mathrm{M}), 5.61$ $(1 \mathrm{H}$, d of dd, $\mathrm{J}=10.7$ and $2 \mathrm{~Hz}), 6.07(1 \mathrm{H}, \mathrm{dt}, \mathrm{J}=10.7$ and $7 \mathrm{~Hz}$ ). Mass spectrum $\left.\mathrm{M}^{+}-\mathrm{C}_{5} \mathrm{H}_{5}\right) ; 269,267\left(\mathrm{M}^{+}-\mathrm{Br}\right)$.

trans-Pinnatifidenyne-8,9-epoxide 5. Treatment of trans-pinnatifidenyne $2(120 \mathrm{mg})$ in dry benzene $(10 \mathrm{ml})$ with $m$-chloroperbenzoic acid $(100 \mathrm{mg})$ in benzene $(10 \mathrm{ml})$ in the same manner as described above for 1 gave, after plc purification, transpinnatifidenyne-8,9-epoxide $5(67 \mathrm{mg}, 56 \%)$ : oil, $\{\alpha\}_{\mathrm{D}}^{25}+87$ (c, 11.8, $\mathrm{CHCl}_{3}$ ). IR (film) $3290,2930,1450,1380,1070,960$ and $800 \mathrm{~cm}^{-1}$. ${ }^{1} \mathrm{H}-\mathrm{NMR}\left(60 \mathrm{MHz}, \mathrm{CCl}_{4}\right) \delta 1.07(3 \mathrm{H}, \mathrm{t}, \mathrm{J}=7.2 \mathrm{~Hz}), 2.83$ $(1 \mathrm{H}, \mathrm{d}, \mathrm{J}=1.7 \mathrm{~Hz}), 3.85(1 \mathrm{H}, \mathrm{m}), 5.59(1 \mathrm{H}, \mathrm{d}$ of dd, $\mathrm{J}=16.3$ and $1.7 \mathrm{~Hz}), 6.16(1 \mathrm{H}, \mathrm{dt}, \mathrm{J}=16.3$ and $7 \mathrm{~Hz})$. Mass spectrum $\mathrm{M}^{+}$at mle $350,348,346\left(\mathrm{C}_{15} \mathrm{H}_{20} \mathrm{BrClO}_{2}\right) ; 285,283,281\left(\mathrm{M}^{+}-\mathrm{C}_{5} \mathrm{H}_{5}\right) ; 269$, $267\left(\mathrm{M}^{+}-\mathrm{Br}\right)$.

Hexahydropinnatifidenyne-8,9-epoxide 6. (A) From cis-pinnatifidenyne-8,9-epoxide 4. Catalytic hydrogenation of 4 over $\mathrm{PtO}_{2}$ in ethyl acetate for $30 \mathrm{~min}$ gave the hexahydro derivative 6 in $87 \%$ yield after plc ( $10 \%$ diethyl ether- $n$-hexane) purification: colourless oil, $\{\alpha\}_{\mathrm{D}}^{25}+22.3$ (c, 11.8, $\mathrm{CHCl}_{3}$ ). IR $\left(\mathrm{CHCl}_{3}\right) 2950$, $1650,1465,1435,1390,1290,1270,1240,1190,1160$ and $970 \mathrm{~cm}^{-1}$. Mass spectrum $\mathrm{M}^{+}$at $m / e$ 356, 354, $352\left(\mathrm{C}_{15} \mathrm{H}_{26} \mathrm{BrCl}_{2} \mathrm{O}_{2}\right) ; 285$, 283, $281\left(\mathrm{M}^{+}-\mathrm{C}_{5} \mathrm{H}_{11}\right) ; 240,238,236\left(\mathrm{M}^{+}-\mathrm{C}_{7} \mathrm{H}_{11} \mathrm{O}\right)$.

(b) From trans-pinnatifidenyne-8,9-epoxide 5. Hydrogenation of 5 for $30 \mathrm{~min}$ in the same manner as described above for $\mathbf{4}$ gave in $82 \%$ yield after ple the hexahydro derivative 6 , colourless oil, $\{\alpha\}_{\mathrm{D}}^{25}+19.8$ (c, 1.13, $\left.\mathrm{CHCl}_{3}\right)$. IR, NMR and MS same as described in (A) above.

Treatment of $(6 \mathrm{R}, 7 \mathrm{R})$ - 3,3 - cis,9 - cis, 12 - cis - 6 - acetoxy - 7 chloro - pentadeca - 3,9,12 - trien - 1 - yne 8 with $\mathrm{K}_{2} \mathrm{CO}_{3}$. Potassium carbonate $(100 \mathrm{mg})$ was added to a magnetically stirred soln of compound $8(45 \mathrm{mg}, 0.15 \mathrm{mmol})$ in $30 \mathrm{ml}$ of $\mathrm{MeOH}$. After $2 \mathrm{hr}$ at room temp, $50 \mathrm{ml}$ of diethyl ether was added and the supernatant decanted from the solid. The solid residue was washed thoroughly 3 times with $10-\mathrm{ml}$ portions of ether. The combined organic solution was passed through a short pad of Florisil and the solvent was removed by distillation. The residue was applied to one preparative plate and this was eluted 3 times with light petroleum-ether $(20: 1)$. The less polar band offered the epoxide 12, as a colourless oil ( $25 \mathrm{mg}$ ). IR (film) $3290,3000,2950$, $2920,2880,1715,1450,1450,1575,1260,1110$ and $960 \mathrm{~cm}^{-1}$. ${ }^{1} \mathrm{H}-\mathrm{NMR}\left(90 \mathrm{MHz}, \mathrm{CDCl}_{3}\right) 0.97(3 \mathrm{H}, \mathrm{t}, \mathrm{J}=7.5 \mathrm{~Hz}), 2.08(2 \mathrm{H}, \mathrm{m})$, $2.40(2 \mathrm{H}, \mathrm{m}), 2.62(2 \mathrm{H}, \mathrm{m}), 2.82(2 \mathrm{H}, \mathrm{m}), 3.00(2 \mathrm{H}, \mathrm{m}), 3.15(1 \mathrm{H}$ $\mathrm{d}, \mathrm{J}=2 \mathrm{~Hz}), 5.44(4 \mathrm{H}, \mathrm{m}), 5.73(1 \mathrm{H}, \mathrm{dd}, \mathrm{J}=7$ and $2 \mathrm{~Hz}), 6.11$ $(1 \mathrm{H}, \mathrm{dt}, \mathrm{J}=7$ and $6 \mathrm{~Hz})$. Mass spectrum $\mathrm{M}^{+}$at m/e 216 $\left(\mathrm{C}_{15} \mathrm{H}_{20} \mathrm{O}\right), 198\left(\mathrm{C}_{15} \mathrm{H}_{18}\right), 151\left(\mathrm{C}_{10} \mathrm{H}_{15} \mathrm{O}\right), 133\left(\mathrm{C}_{10} \mathrm{H}_{13}\right)$.

The second band offered the alcohol 9 as an oil (11 mg): IR (film) 3440, 3290, 3010, 2960, 2920, 2870, 1430, 1380, 1260, 1090 and $965 \mathrm{~cm}^{-1} .{ }^{1} \mathrm{H}-\mathrm{NMR}$ spectrum $\left(90 \mathrm{MHz}, \mathrm{CDCl}_{3}\right): 80.97(3 \mathrm{H}, \mathrm{t}$, $\mathrm{J}=7.5 \mathrm{~Hz}), 2.06(2 \mathrm{H}, \mathrm{m}), 2.44(2 \mathrm{H}, \mathrm{m}), 2.66(2 \mathrm{H}, \mathrm{m}), 2.82(2 \mathrm{H}$, m), $3.14(1 \mathrm{H}, \mathrm{d}, \mathrm{J}=2 \mathrm{~Hz}), 3.86(1 \mathrm{H}, \mathrm{m}), 3.92(1 \mathrm{H}, \mathrm{m}), 5.42(4 \mathrm{H}$, $\mathrm{m}), 5.64(1 \mathrm{H}, \mathrm{dd}, \mathrm{J}=7$ and $2 \mathrm{~Hz}), 6.16(1 \mathrm{H}, \mathrm{dt}, \mathrm{J}=7$ and $6 \mathrm{~Hz})$. Mass spectrum $\mathrm{M}^{+}$at m/e 254, $252\left(\mathrm{C}_{15} \mathrm{H}_{21} \mathrm{ClO}\right), 217\left(\mathrm{C}_{15} \mathrm{H}_{21} \mathrm{O}\right)$, $199\left(\mathrm{C}_{15} \mathrm{H}_{19}\right), 189,187\left(\mathrm{C}_{10} \mathrm{H}_{16} \mathrm{ClO}\right), 171,169\left(\mathrm{C}_{10} \mathrm{H}_{14} \mathrm{Cl}\right), 159,157$ $\left(\mathrm{C}_{9} \mathrm{H}_{14} \mathrm{Cl}\right), 151\left(\mathrm{C}_{10} \mathrm{H}_{15} \mathrm{O}\right), 145,143\left(\mathrm{C}_{7} \mathrm{H}_{8} \mathrm{ClO}\right), 133\left(\mathrm{C}_{10} \mathrm{H}_{13}\right), 129$ $\left(\mathrm{C}_{10} \mathrm{H}_{9}\right), 109\left(\mathrm{C}_{8} \mathrm{H}_{13}\right), 95\left(\mathrm{C}_{6} \mathrm{H}_{7} \mathrm{O}\right), 65\left(\mathrm{C}_{5} \mathrm{H}_{5}\right)$.

When the reaction was run at $0^{\circ}$, the alcohol 9 , was the only compound isolated $(92 \%)$. When the reaction was left at room temp overnight the epoxide 12 was isolated in $97 \%$ yield.

Treatment of cis-pinnatifidenyne 1 with $\mathrm{Zn}-\mathrm{AcOH}-\mathrm{EtOH}$. A soln of cis-pinnatifidenyne $1(315 \mathrm{mg}, 0.95 \mathrm{mmol})$ in EtON $(10 \mathrm{ml})-\mathrm{AcOH}(5 \mathrm{ml})$ was stirred while $\mathrm{Zn}$ dust $(100 \mathrm{mg})$ was added portionwise during $15 \mathrm{~min}$. The reaction mixture was kept at room temp for $2 \mathrm{hr}$. The $\mathrm{Zn}$ was filtered off and the filtrate was worked up in the normal way to yield a residue $(215 \mathrm{mg})$ which was dissolved in $n$-hexane and chromatographed on a silica gel $(40 \mathrm{~g})$ column. Compound 13 was eluted with $n$-hexane-ethyl acetate $(9: 1)$ as a colourless oil $(159 \mathrm{mg}, 50.4 \%$ ). IR (film) 3420,3020 , $2970,2940,1650,1600,1440,1380,1315,1280,1080,1005,975$ and $915 \mathrm{~cm}^{-1}$. UV $\lambda_{\max }(\mathrm{EtOH}) 234 \mathrm{~nm} \quad(\epsilon=13300)$. ${ }^{1} \mathrm{H}-\mathrm{NMR}$ $\left(90 \mathrm{MHz}, \mathrm{CCl}_{4}\right) \delta 0.97(3 \mathrm{H}, \mathrm{t}, \mathrm{J}=7.2 \mathrm{~Hz}), 2.08(2 \mathrm{H}, \mathrm{m}), 2.64(6 \mathrm{H}$, 
m), $3.77(2 \mathrm{H}, \mathrm{m}), 5.35(7 \mathrm{H}, \mathrm{m}), 6.05(1 \mathrm{H}, \mathrm{t}, \mathrm{J}=7 \mathrm{~Hz}), 6.62(1 \mathrm{H}$, $\mathrm{dt}, \mathrm{J}=7$ and $6 \mathrm{~Hz}$ ). Mass spectrum $\mathrm{M}^{+}$at $m / e \cdot 256,254$ $\left(\mathrm{C}_{15} \mathrm{H}_{23} \mathrm{ClO}\right), 219\left(\mathrm{C}_{15} \mathrm{H}_{23} \mathrm{O}\right), 201\left(\mathrm{C}_{15} \mathrm{H}_{21}\right)$.

Treatment of cis-pinnatifidenyne 1 with $\mathrm{ClSi}\left(\mathrm{CH}_{3}\right)_{3}$. A soln of cis-pinnatifidenyne $1(783 \mathrm{mg}, 2.36 \mathrm{mmol})$ in dry THF $(5 \mathrm{ml})$ under nitrogen at $0^{\circ}$ was stirred while $n$-butyl-magnesium bromide ( $779 \mathrm{mg}, 4.72 \mathrm{mmol}$ ) in $10 \mathrm{ml}$ of THF was slowly added. The addition took $30 \mathrm{~min}$ at $0^{\circ}$. Subsequently, stirring was continued for $15 \mathrm{~min}$. Then $518 \mathrm{mg}(4.72 \mathrm{mmol})$ of trimethylchlorosilane dissolved in $25 \mathrm{ml}$ of dry THF was added in $15 \mathrm{~min}$ at $0^{\circ}$ and stirring was continued for $30 \mathrm{~min}$. The reaction mixture was poured into a concentrated aqueous soln of ammonium chloride. After work-up and chromatography on silica gel $(50 \mathrm{mg})$ $769 \mathrm{mg}$ of the 1-trimethylsilyl derivative of cis-pinnatifidenyne 7 $(80 \%)$ were isolated as a colourless oil: IR (film) $3020,2945,2145$, $1450,1385,1255,1090,1055,1020$ and $850 \mathrm{~cm}^{-1}$. ${ }^{1} \mathrm{H}-\mathrm{NMR}$ $\left(60 \mathrm{MHz}, \mathrm{CCl}_{4}\right) 80.17(9 \mathrm{H}, \mathrm{s}), 1.06(3 \mathrm{H}, \mathrm{t}, \mathrm{J}=7.2 \mathrm{~Hz}), 1.90(2 \mathrm{H}$, $\mathrm{m}), 2.55(6 \mathrm{H}, \mathrm{m}), 3.50(2 \mathrm{H}, \mathrm{m}), 3.88(2 \mathrm{H}, \mathrm{m}), 5.80(4 \mathrm{H}, \mathrm{m})$. Mass spectrum: $\mathrm{M}^{+}$at m/e $406,404,402\left(\mathrm{C}_{18} \mathrm{H}_{28} \mathrm{BrClOSi}\right) ; 325,323$ $\left(\mathrm{C}_{18} \mathrm{H}_{28} \mathrm{ClSOSi}\right) ; 269,267,265 \quad\left(\mathrm{C}_{10} \mathrm{H}_{15} \mathrm{BrClO}\right) ; \quad 187, \quad 185$ $\left(\mathrm{C}_{10} \mathrm{H}_{14} \mathrm{ClO}\right) ; 145,143\left(\mathrm{C}_{7} \mathrm{H}_{8} \mathrm{ClO}\right) ; 107\left(\mathrm{C}_{7} \mathrm{H}_{7} \mathrm{O}\right) ; 91\left(\mathrm{C}_{7} \mathrm{H}_{7}\right) ; 73$ $\left(\mathrm{C}_{3} \mathrm{H}_{9} \mathrm{Si}\right)$.

Treatment of 7 with $\mathrm{Zn}-\mathrm{AcON}-\mathrm{EtOH}$. A soln of $7(454 \mathrm{mg}$, $1.125 \mathrm{mmole})$ in EtOH $(10 \mathrm{ml})-\mathrm{AcOH}(5 \mathrm{ml})$ was stirred while $\mathrm{Zn}$ dust $(120 \mathrm{mg})$ was added portionwise during $20 \mathrm{~min}$. The reaction mixture was stirred at room temp overnight. The $Z N$ was filtered off and the filtrate was added to a soln of $\mathrm{NaHCO}_{3} \mathrm{aq}$ and the whole extracted with ether. The ether soln was washed with $2 \mathrm{~N} \mathrm{NaOH}$ and water, dried over $\mathrm{Na}_{2} \mathrm{SO}_{4}$ and the solvent evaporated. The crude product (362 mg) was chromatographed using benzene- $\mathrm{CHCl}_{3}(1: 1)$ as eluent to give the 1-triemethylsilyl derivative of cis, cis, cis - $6 R$ hydroxy $-7 R$ - chloro-pentadeca - 3,9,12 - trien - 1 - yne, compound 10, as an oil ( $264 \mathrm{mg}, 0.81 \mathrm{mmole}, 72 \%$ ): IR (film) 3430 , $3015,2960,2155,1710,1440,1345,1255,1050,970,845,755$ and $705 \mathrm{~cm}^{-1}$. ${ }^{1} \mathrm{H}-\mathrm{NMR}\left(60 \mathrm{MHz}, \mathrm{CCl}_{4}\right): \delta 0.22(9 \mathrm{H}, \mathrm{s}), 0.96(3 \mathrm{H}, \mathrm{t}$, $\mathrm{J}=7.5 \mathrm{~Hz}), 2.03(2 \mathrm{H}, \mathrm{m}), 2.52(4 \mathrm{H}, \mathrm{m}), 2.73(2 \mathrm{H}, \mathrm{m}), 3.76(1 \mathrm{H}$, $\mathrm{m}), 3.86(1 \mathrm{H}, \mathrm{m}), 5.46(4 \mathrm{H}, \mathrm{m}), 5.61(1 \mathrm{H}, \mathrm{dd}, \mathrm{J}=7$ and $2 \mathrm{~Hz})$, $6.07(1 \mathrm{H}, \mathrm{dt}, \mathrm{J}=7$ and $6 \mathrm{~Hz})$. Mass spectrum: $\mathrm{M}^{+}$at $\mathrm{m} / \mathrm{e} 326,324$ $\left(\mathrm{C}_{18} \mathrm{H}_{29} \mathrm{ClOSi}\right) ; 289\left(\mathrm{C}_{18} \mathrm{H}_{29} \mathrm{OSi}\right) ; 271\left(\mathrm{C}_{18} \mathrm{H}_{27} \mathrm{OSi}\right) ; 271\left(\mathrm{C}_{18} \mathrm{H}_{27} \mathrm{Si}\right)$; $271\left(\mathrm{C}_{18} \mathrm{H}_{27} \mathrm{Si}\right) ; 253,251\left(\mathrm{C}_{15} \mathrm{H}_{20} \mathrm{ClO}\right) ; 197\left(\mathrm{C}_{15} \mathrm{H}_{17}\right) ; 73\left(\mathrm{C}_{3} \mathrm{H}_{9} \mathrm{Si}\right)$.

Acetate 11, from $\mathrm{Ac}_{2} \mathrm{O}-\mathrm{Py}$ at room temp overnight, colourless oil, IR (film) 3005, 2950, 2145, 1740,1435, 1375, 1225, 1035, 970, 850,765 and $705 \mathrm{~cm}^{-1} .{ }^{1} \mathrm{H}-\mathrm{NMR}\left(60 \mathrm{MHz}, \mathrm{CCl}_{4}\right): 80.17(9 \mathrm{H}, \mathrm{s})$, $0.95(3 \mathrm{H}, \mathrm{t}, \mathrm{J}=7.2 \mathrm{~Hz}), 2.01(2 \mathrm{H}, \mathrm{m}), 2.06(3 \mathrm{H}, \mathrm{s}), 2.48(2 \mathrm{H}, \mathrm{m})$, $2.60(2 \mathrm{H}, \mathrm{m}), 2.72(2 \mathrm{H}, \mathrm{m}), 3.90(1 \mathrm{H}, \mathrm{m}), 5.11(1 \mathrm{H}, \mathrm{m}), 5.45$ $(4 \mathrm{H}, \mathrm{m}), 5.56(1 \mathrm{H}, \mathrm{dd}, \mathrm{J}=7.5 \mathrm{AND} 2 \mathrm{~Hz}), 5.76(1 \mathrm{H}, \mathrm{dt}, \mathrm{J}=6$ and $7 \mathrm{~Hz})$. Mass spectrum, m/e 308, $306\left(\mathrm{C}_{18} \mathrm{H}_{27} \mathrm{ClSi}\right) ; 271\left(\mathrm{C}_{18} \mathrm{H}_{27} \mathrm{Si}\right)$; $197\left(\mathrm{C}_{15} \mathrm{H}_{18}\right) ; 171,169\left(\mathrm{C}_{10} \mathrm{H}_{14} \mathrm{Cl}\right) ; 73\left(\mathrm{C}_{3} \mathrm{H}_{9} \mathrm{Si}\right)$.

Treatment of 11 with $\mathrm{NaF}$ in aqDMF. To a soln of the silylated trienyne 11 ( $65 \mathrm{mg}, 0.18 \mathrm{mmole})$ in DMF $(50 \mathrm{ml})$ was added excess of $\mathrm{NaF}$ in water. The reaction mixture was kept for $4 \mathrm{hr}$ at $40^{\circ}$. After work-up with water and $n$-hexane the crude reaction product $(58 \mathrm{mg})$ was chromatographed using benzene$\mathrm{CHCl}_{3}(5: 1)$ as eluent to give $44 \mathrm{mg}(0.15 \mathrm{mmole}(94 \%)$ of: $(6 R, 7 R)$ - 3 - cis,9 - cis,12 - cis,6 - acetoxy - 7 - chloro - pentadeca $-3,9,12$ - trien -1 - yne 8 as a colourless oil, $\{\alpha\}_{D}+4.2$ (c, 1.18 , $\mathrm{CHCl}_{3}$ ). The physical and spectrocopic data (tlc, glc, IR, PMR, MS) was identical with those obtained from the naturally occurring compound.
Acknowledgements-This research was supported in part by Grant No. $4125-79$ awarded by C.A.I.C.T. (A.G.G.) and by an N.I.H. Grant CA-24487 (J.C.). The instrument support provided by the NMR Center, S.M.R.L., supported by the Grant Numbers NSF\#6P23633 and NIH\#RR00711, is gratefully acknowledged.

\section{REFERENCES}

${ }^{1}$ Part 25 in the series Marine Natural Products from the Atlantic Zone. For part 24 see: A. G. González, J. Darias, J. D. Martín, V. S. Martín, M. Norte, C. Pérez, A. Perales and J. Fayos, Tetrahedron Letters 1151 (1980).

${ }^{2}$ A. G. González, J. D. Martín and J. Darias, Ibid. 2381 (1973); Ibid 3625 (1973); A. G. González, J. Darias, J. D. Martín and C. Pérez, Ibid. 1249 (1974); A. G. González, J. M. Aguiar, J. D. Martín and M. Norte, Ibid. 2499 (1975); A. G. González, J. M. Aguiar, J. D. Martín and M. L. Rodríguez, Ibid. 205 (1976); A. G. González, J. Darias, J. D. Martín, J. D. Fourneron and C. Pérez, Ibid. 3051 (1976); A. G. González, J. D. Martín, V. S. Martín and M. Norte, Ibid. 2035 (1978); A. G. González, J. M. Aguiar, J. Darias, J. D. Martín, E. González, V. S. Martín, C. Pérez, J. Fayos and M. Martínez-Ripoll, Ibid. 3981 (1978); A. G. González, J. D. Martín, V. S. Martín, M. Martínez-Ripoll and J. Fayos, Ibid. 2717 (1979).

${ }^{3} J$. D. Martín and J. Darias, Algal Sesquiterpenoids in Marine Natural Products, (Edited by P. J. Scheuer), Vol. 1, pp. 125-175. Academic Press, New York (1978).

${ }^{4}$ R. E. Moore, Algal Nonisoprenoids in Marine Natural Products (Edited by P. J. Scheuer), Vol. 1, pp. 44-121. Academic Press, New York (1978); R. H. White and L. P. Hager, Phytochemistry 17, 939 (1978); T. J. King, S. Imre, A. Oztunc and R. H. Thomson, Tetrahedron Letters 1453 (1979); A. Fuzukawa and E. Kurosawa, Ibid. 2797 (1979); B. M. Howard, W. Fenical, E. V. Arnold and J. Clardy, Ibid. 2841 (1979); B. M. Howard, W. Fenical, K. Hirotsu, B. Solheim and J. Clardy, Tetrahedron 36, 171 (1980); S. Caccmese, R. Azzolina, E. N. Duesler, I. C. Paul and K. L. Rinehart, Jr., Tetrahedron Letters 2299 (1980); E. N. Duesler, K. L. Rinehart, I. C. Paul, S. Caccmese and R. Azzolina, Cryst. Struct. Comm. 9, 777 (1980); C. P. Falshaw, T. J. King, S. Imre, S. Islimyeli and R. H. Thomson, Tetrahedron Letters 4951 (1980); M. Suzuki and E. Kurosawa, Chemistry Letters 1177 (1980).

${ }^{5}$ F. J. McDonald, D. C. Campbell, D. J. Vanderah, F. J. Schmitz, D. M. Washecheck, J. E. Burns and D. Van der Helm, J. Org. Chem. 40, 665 (1975); D. J. Vanderah and F. J. Schmitz, Ibid. 41, 3480 (1976); R. Kinnel, A. J. Duggan, T. Eisner and J. Meinwald, Tetrahedron Letters 3913 (1977).

${ }^{6}$ Crystallographic data have been deposited with the Cambridge Crystallographic Data Centre. Tables of fractional coordinates, thermal parameters, bond distances, bond angles and observed and calculated structure factors, are available from JC.

${ }^{7}$ B. M. Howard, W. Fenical, K. Hirotsu, B. Solheim and J. Clardy, Tetrahedron 36, 171 (1980).

${ }^{8}$ E. Kurosawa, A. Fukuzawa and T. Irie, Tetrahedron Letters 2121 (1972).

${ }^{9}$ E. J. Corey and R. A. Ruden, Ibid. 1495 (1973).

${ }^{10}$ J. Drouin, F. Leyendecker and J. M. Conia, Ibid. 4053 (1975). 